dinal series: upon the pinnæ they are absent for a very short distance at the base; then a single one appears first upon the lower aspect of the branch; and the series thence ascends in a close spiral. Afterwards the spiral arrangement becomes lost or obscured, and we see simply the longitudinal rows, which on the pinnæ seem not to exceed the number of five or six. But, as M. Mereschkowsky has observed in the case of $S$. decemserialis, this limit is not to be considered absolutely constant; for since the fundamental arrangement is a close spire, the apparent number of rows of hydrothecæ will always depend upon the thickness of the pinna they surround.

The present species seems to be most nearly related to $S$. mirabilis, Verrill, from which, however, it differs markedly in the numerous rows of hydrothecæ on the main stem, these being reduced to two in the allied species.

However similar all the species which have been ascribed to Selaginopsis are as regards the form and general arrangement of the hydrothecæ, I am yet doubtful whether a generic separation might not still be made with advantage between those forms which are simply pinnate and those whose branches lie in all planes or are disposed in a more or less irregular manner.

XI.-On the Bryozoa (Polyzoa) of the Bay of Naples. By Arthur Wis. Waters, F.G.S.

[Plates XII.-XV.]

[Continued from p. 43.]

The same plan will be followed in this as in the previous part, of only giving the synonyms where there is any special reason for doing so ; but for the long list of synonyms which most species possess the reader is referred to the works of Smitt and Busk.

\title{
Cheilostomata (continued).
}

\section{Aetea anguina, L., forma recta.}

(Pl. XV. fig. 7.)

Atea recta, Hincks, Cat. of Zooph., Ann. \& Mag. Nat. Hist. 3rd ser. vol. ix. p. 25 , pl. vii. fig. 3 .

Atea anguina, forma recta, Smitt, Krit. Fört. 1867, p. 281, pl. xvi. figs. $5,6$.

? Etea ligulata, Busk, Cat. Mar. Polyz. p. 31, pl. xlii.

The difficulty is very great as to the position of Aetea, as it has relationships with the Cheilostomata and also with the Ctenostomata (in having a collar as seen in the Naples specimens, and which Smitt pointed out in 1867); and whether it will have to be placed in a new suborder (Stolonata, Claus, 
or Stolonifera, Ehlers*) is yet problematic, and its usual position is retained.

Mr. Busk † says (p. 125), "the polype, as far as I have observed, is always lodged in the upright portion of the cell." This certainly is not the case in this species; for the polypide is sometimes entirely in the lower part, though more often projecting slightly into the raised tube, as seen in the righthand cell of the figure. This necessitates a change in the generic characters; and the erect tubular portion must be regarded as a prolongation of the horizontal zoocium.

The zoocia bud from the end and from the sides, starting from a round disk or rosette-plate; and from similar plates on the side grow tubes bearing round or elongate cells which do not develop into zoccia; but as their mode of growth is so similar, perhaps they are abortive zoœcia. Hincks mentions spur-like processes which start from the back of the cell of $A$. truncata; but from his description these are radicles. May the spinous processes of his Farrella dilatata be at all the same as the present?

The length of the erect prolongation of the zoœcia (formerly the cell) is very variable, but, as a rule, is considerable; and the creeping tubes connecting the zoœcia are also very variablesometimes appearing like a thread for four or five times the length of the ventricose expansion, while in other cases the zoœcium expands close to the rosette-plate of the parent zoøecium.

When dry the tubes contract in the middle as in A. ligulata (which in the British-Museum Catalogue is evidently drawn from a dried specimen), and have just the same appearance, with the exception of the lower part being ringed; but this is not always easily made out in dry specimens from Naples, as it is not so marked as in the ordinary anguina. I noticed in the British-Museum collection that the Aeteidæ dissolved the shelis on which they grew, and thus a permanent record is left. It is known that several Bryozoa have this power; and the idea suggests itself that some of the phenomena mentioned by Fischer $\ddagger$ are of this kind, and it may not be useless to point out that in many cases it is impossible to distinguish fossil Aetea from Hippothoa.

The Stomatopora gallica, D'Orb., is Aetea; but the other species of the genus probably belong to Alecto and Hippothoa.

* "Hypophorella expansa. Ein Beitr. zur Kenntn. der minirenden Bryozoen, von E. Ehlers," Kön. Gesellsch. d. Wissensch. Göttingen, 1867.

+ "Observations on the Anguinaria spathulata," Trans. Micr. Soc. p. 123, vol. ii. (1849).

† "Etudes sur les Bry. perforants de la fam. des Térébriporides," Nouv. Arch. du Mus. d'Hist. Nat. Paris, t. ii. 1866; and Quart. Journ. Micr. Sc. vol. viii. p. 279. 


\section{Eucratea Lafontii, Aud.}

Eucratea Lafontii, Aud. in Savigny, Egypte, pl. xiii. fig. 2.

Alysidium Lafontii, Busk, Mar. Polyz. p. 14, pl. xiv. figs. 1-4.

As Eucratea chelata and E. Cordieri have so close a resemblance, I cannot bring my mind to place them in two genera merely because the latter has a horny connexion. The Alysidium parasiticum, Busk, being also closely allied to $E$. Cor dieri, Aud., the genus Alysidium seems a superfluity, and the definition of Eucratea should be changed to admit Alysidium. Hab. Spain, Adriatic, 25-5.5 fathoms; Naples on seaweed from but slight depths.

\section{Eucratea Cordieri, Aud. (Pl. XV. figs. 9, 10, 11.)}

Eucratea Cordieri, Aud. in Savigny, Egypte, p. 74, pl. 13. fig. 3.

Several branches of cells curving inwards, growing on a jointed stalk, rising from ereeping anastomosing stolons; zoœcia nearly straight in front, curved behind, narrowing to the proximal end; zoøcia growing from the end of the cell, connected by short corneous tubes. Zoœcium in front coffinshaped with an opening below the oral aperture.

This is clearly the form figured by Savigny, and differs from Eucratea chelata in having no raised border, which is very apparent in the British species, as far as my opportunities of examination extend. This, however, seems to be somewhat variable, as Prof. Smitt says this border seems to be more common in his southern stations, and in his northern ones is not so distinct as in the English figures. It also differs from $E$. chelata in not having rigid junctions; and according to Mr. Busk's definition of Scruparia, should not be considered of this genus; but with the mode of growth and the shape of the cells so similar, it would hardly be justifiable to make two genera out of them at present. This, however, would unite Alysidium parasiticum, Busk, under the same genus; and in many points it has much in common with the present form.

From one piece of seaweed there are about fifteen colonies, all connected together by one creeping and anastomosing root. The stem rises up from this radicle, from a round disk which corresponds with the rosette-plates. This stalk consists of 6-10 joints (figs. 9,10 ) with, usually, long calcareous tubes and short horny tubes, though occasionally the corneous tube is about as long as the calcareous one. At the top of the stem the joint bifurcates; and from these and other bifurcations branches are given off with about $6-8$ zoœeia, curling over and mostly opening in the same direction. The figure 9 only 
shows a small specimen, and in larger ones there are about three times as many branches as are shown.

The zoøecium when seen from the front is coffin-shaped, with the aperture at the top and a nearly circular opening: below it (as in Lepralia violacea). The operculum is semicircular, with a straight proximal end and large muscular projections on each side. The tube from each cell emerges from a small chamber (see fig. 11) at the top of the cell; and in the lower wall of this chamber is apparently one rosette-plate.

Hab. Red Sea and Mediterranean (Aud.).

I did not find Eucratea chelata at Naples; but it is reported to have been found in the Mediterranean. Eucratea has been described fossil as Unicrisia (tenerrima \&c., in the Eocene); but a small-jointed species like the present would probably be overlooked even if it occurs.

\section{Cellularia reptans, L.}

Canda reptans, Busk, Mar. Polyz. p. 26, pl. xxi. figs. 3, 4 .

Seas of Europe from Norway to Mediterranean.

38. Cellularia scruposa, L.

Serupocellaria scruposa, Busk, Mar. Polyz. p. 25, pl. xxii. figs. 3, 4.

Hab. Brit., Medit., France (J.), Scandinavia (Sm.), Adriatic, Iceland, St.-Lawrence Bay (Kirchenpauer); common at Naples from all depths.

\section{Cellularia scrupea.}

Scrupocellaria scrupea, Busk, Mar. Polyz. p. 24, pl. xxi. figs. 1, 2.

\section{Beania mirabilis, Johnst.}

$H a b$. Britain, France (zone litt. et prof., J.), Ireland (H.), Adriatic $(H$.$) , Scandinavia (S m$.$) ; Naples 8-12 fathoms and$ 30 fathoms, rare.

41. Bugula avicularia, Pall., forma flabellata, Thomps.

The ovicell has not so wide an opening as in the specimen figured by Busk.

$H a b$. Scandinavia $(S m$.$) , seas of Europe; Naples, not rare$ in moderate depths.

\section{Bugula avicularia, L.}

Bugula avicularia, forma avicularia, Smitt, Kr. Fört. Sk. H.-Bry. 1867, p. 289, pl. xviii. figs. 9-18.

At the back, just above the light cuneiform area, is a beading of about ten circles on each side; each shows a light 
spot in the centre. May these perform the same functions as the pore-tubes or the rosette-plates?

$H a b$. Scandinavia, Finland, and Spitzbergen, and all seas of Europe.

\section{Bugula fastigiata, L.}

Bugula plumosa, Pall., B.M. Cat. p. 45, pl. liv.

Bugula avicularia, forma fastigiata, Smitt, Krit. Fört. Skand. H.-Bry. 1867, p. 291, pl. xviii. figs. 16-18.

\section{Cellaria fistulosa, L.}

Salicornaria farciminoides, Ell. \& Sol., Busk, Mar. Polyz. p. 16, pI. lxiv. figs. 1, 2, 3, pl. lxv. bis. fig. 5 .

Cellaria fistulosa, L., Smitt, Krit. Fört. ö. Sk. Hafs-Bry. 1867, p. 362, pl. xx. figs. 18-20.

For synonyms see Smitt and Reuss.

Found in the Scandinavian seas and generally in Europe; also Algoa Bay; and in Europe has been found in the Eocene, Miocene, and Pliocene. In Naples at all depths greater than 10 fathoms.

\section{Tubucellaria cereoides, Ell. \& Sol.}

Cellaria Michelini, Reuss, Foss. Pol. d. W. Tert. p. 61, pl. viii. figs. 1, 2 .

Onchophora tubulosa, Busk, Quart. Journ. Micr. Sci. 1855, vol. iii. p. 320 , pl. iv. fig. 1 .

For a list of synonyms see Reuss, Foss. Bryoz. des Oest.-Ung. Miocäns, p. 6 ; and see pl. xi. figs. 11-15, pl. xii. figs. 1, 2 .

The genus under its different synonyms has been sometimes described as having only one corneous tube to each new branch, which is not the case; for sometimes several tubes grow out of the aperture of neighbouring cells, and from these are produced the basal cells of a new branch.

The operculum $(36 \% \& 37 \%)$ in this species is very characteristic. It is suboval with a slightly flattened proximal end; near the sides are the muscular processes; the centre is lighter on account of there being a double chitinous layer over all but the centre ; width 0.13 millim., length 0.06 . The operculum is situated at the bottom of the tubular peristome.

In the apex of the subtriangular distal wall there is one rosette-plate near the centre of the zoarium. In the lateral walls there are four, two near the middle of the zoarium and two above, further removed. It is not without interest to find that in a closely allied species, T. hirsuta (Onchophora hirsuta, Busk, = Margaretta barbata, Hutton), there is a slight difference in both operculum and rosette-plates, by which they may be distinguished. 
Loc. Eocene: Grignon, Parnes (Mich.). Oligocene: Latdorf and Val di Lonte. Miocene: many localities in Austria and Hungary. Pliocene: Asti, Pisa, Castellarquato, Rhodes. Living: Adriatic (H.), Egean (B.), Indian Ocean (Reuss). There is a specimen in the British Museum from Dr. Bowerbank's collection from Australia, in which I do not see any difference from the Naples specimen; but I should not like to speak positively unless I have the opportunity of detail-examination. Naples, 40-50 fathoms.

\section{Flustra truncata, Linn.}

Eschara securifrons, Pall. Elench. Zooph. p. 56.

Flustra securifrons, Smitt, Krit. Fört. ö. Sk. Hafs-Bry. 1867, pt. iii. p. 358 , pl. xx. figs. $6-8$.

Flustra truncata, Busk, Cat. Mar. Polyz. p. 48, pl. lviii. figs. 1, 2, and pl. lvi. figs. 1, 2.

Although no spines are apparent when a colony is examined, thin transverse sections show two microscopical spines near the oral aperture.

This, like Flustra papyrea, is found occasionally on the back of Pisa armata, and also in dredging from 40 fathoms in the Secca. Occasionally the avicularia are placed diagonally.

Rosette-plates, four distal and eight lateral.

Hab. Spitzbergen, Scandinavia (all depths), Britain, Atlantic, Adriatic (Heller), Australia (Busk).

\section{Flustra papyrea, Pall.}

Carbasea papyrea, Busk, Cat. Mar. Polyz. p. 50, pl. xlix. figs. 1-3 (?).

Flustra papyrea, Smitt, Kr. Fört. ö. Sk. Hafs-Bry. pt. iii. 1867, p. 359, pl. xx. figs. 9-11.

Plates 49 and 50 of Mr. Busk's catalogue have evidently been changed, requiring renumbering of the plates or alteration of the text.

This is very common upon a crab (Pisa armata), which usually carries a small colony of this Flustra on its back. I do not remember seeing any at Naples except from this crab.

There is one distal and usually two lateral rosette-plates *:

$\mathrm{Hab}$. Arctic seas at various depths $(\mathrm{Sm}$.$) , Britain, Adri-$ atic (Heller).

Although specially on the look-out for Flustra foliacea, I was surprised not to find any.

* In Flustra armata, pl. 50. fig. 4, of Brit. Mus. Cat., the rosette-plates are shown but are not mentioned. 
48. Diachoris patellaria, Moll. (Pl. X. figs. 6, 7, 8, 9.)

Eschara patellaria, Moll, Die Seerinde, p. 75, pl. iv. fig. 20.

Diachoris simplex, Heller, Bry. Adr. Meeres, p. 94, pl. i. fig. 4.

Mollia patellaria, Smitt, Floridan Bry. p. 12, pl. ii. fig. 72 .

The ovicells are situated on the distal end of the zoœcia, and are sometimes seen to coalesce with the cell above. The smaller openings (fig. 6), I presume, show an incompleted stage of growth; but if this is the explanation it would seem as if the growth of the ovicells influenced the growth of neighbouring cells, as in my specimen some of the cells near the ovicells have only this small subcentral opening, while all the neighbouring cells have the usual aperture.

The lower two thirds of the front is covered with a granulated calcareous wall, the rest is covered with a thin membrane; the small lid of the oral aperture is near the distal end ; border much raised and granulated.

The attachment of this species is very strange, as from the base (figs. 8, 9) there are thrown out a number of radicular fibres, by which the colony is fastened to stones, sponges, \&c.

49. Diachoris patellaria, Moll, var. multijuncta.

(Pl. XIIT. fig. 4.)

?Eschara depressa, Moll, Die Seerinde, p. 76, fig. 21.

This differs from $D$. patellaria in having from eight to twelve or more tubular processes, and in the cells being longer and somewhat irregular in shape. The length of the tubular processes is also very variable; and the cells, in consequence of shorter tubes, are often close together. In such cases I am unable to see wherein it differs from Membranipora circumcincta of Heller (Bry. des Adriat. Meeres, p. 96, pl. vi. fig. こ). Professor Heller, to whom I sent this drawing, does not, however, think it is the same; so I suppose there must be some difference.

The definition of Diachoris would require altering to admit this form; but the variations indicate that the tubular processes are not safe generic guides; and this we see in Lepratia Brongniartii with short tubes, $L$. discreta with longer ones, and a form much like discreta, if not the same, which Hutton has called Diachoris Buskiana. The genus Diachoris can only be looked upon as a provisional one, without any scientific basis as at present constituted.

\section{Diachoris magellanica, Busk.}

(Pl. XII. fig. 1.)

Diachoris magellanica, Busk, Mar. Poly. p. 54, pl. lxvii. figs. 1, 2, 3. Diachoris Buskei, Heller, Die Bry. des Adriat. p. 93.

The figure given by Busk is evidently from a dried speci- 
men, and does not give all the characters quite correctly. The mouth is not circular, and has no thickened and raised margin, though when the zoøecial case dries and contracts in the centre it gives this appearance to the aperture. The distal edge is rounded, the proximal nearly straight. Just above the aperture are from two to four small projections on the zoœcium; the tubular processes have a septum in the middle. From the back of each cell grows a long radicular tube $(h)$; and in my specimens, which were attached to sponge, there was a "grappling-hook" $(p)$ at the end. The position of these roots is shown in Busk's figure 2 by the circles, which he does not mention.

In the small piece drawn there are two avicularia to each of the centre cells, while the others have one on the right and left respectively. In larger pieces there are several lines of double avicularia ; but this is subject to some variation.

The piece drawn shows the life-history of the Bryozoa in a very complete manner; and as the walls are transparent, it is a very good species for examination. First at $k$ are the processes, which gradually increase and coalesce as at $m$ and $l$; this grows until an enclosed zoœcium as at $a$ is the result, when the polypide begins to bud inside $a$. This grows through $b, c, d$ stages, until at $e$ the polypide is perfect; at $c$ and $d$ the oral opening of the zoccium is formed. At $f$ there is a polypide budding in an older zoœcium; but at $g$ in the same cell is seen a "dark body," which is really the remains of a previous polypide; for after a time each polypide loses vitality and gradually becomes reduced to this "dark body," when another polypide buds from the side.

Loc. Living: Straits of Magellan, New Zealand (Busk), Adriatic (Heller) ; Naples, 30-50 fathoms.

\section{Membranipora pilosa, Pall.}

European seas generally, common. From Australia I have this, if $M$. verticillata, Lamx., is to be considered synonymous.

\section{Membranipora membranacea, L.}

European seas.

\section{Membranipora Rosselii, Aud.}

The calcareous perforated expansion is somewhat smaller than figured by Busk; and if Manzoni's specimen (Bry. Foss. Ital. $4^{\mathrm{a}}$ contr. pl. iii. fig. 15) is really Rosselii, it would seem to be very variable, as the open space there is but little larger 
than the oral aperture. The zoarium is attached to stones \&c. by two to four radicular projections.

One rosette-plate in the middle of the distal wall.

Pliocene : Castrocaro, Castellarquato, Pisa. Pleistocene : Leghorn. Living: Britain, Orkney, Gibraltar, Adriatic (20-55 fathoms); and there is a specimen in the British Museum from Tsos-Sima. At Naples I received it from apparently about 40-50 fathoms.

\section{Membranipora Flemingii, Busk. (Pl. XIII. fig. 2.)}

In the Naples specimens the rather large avicularia are by the side of the globular ovicells. The borders of the cells are usually rather closer together than shown in the figure.

Lateral rosette-plates three, elongate, about equal distance from the base and the front wall.

Loc. Pliocene : Castrocaro (M.). Living: European seas, Australia? (Busk), Adriatic (Heller). At Naples, from just below low-water mark to 40 fathoms; Roscoff (J.).

55. Membranipora Flemingii, Busk, var. gregaria. (Pl. XIII. fig. 5.)

Membranipora gregaria, Heller, Die Bry. des Adriat. Meeres, p. 98, pl. i. fig. 8.

Membranipora aperta, Manzoni, Bri. del Pl. di Castrocaro, p. 9, pl. i. fig. 4 .

The walls are much thinner and placed nearer together than is shown in my drawing.

Membranipora Flemingii is a most variable species; and there does not, to my mind, seem sufficient reason for separating this form, though, as the position of the large avicularium in front of each cell is characteristic, it may be considered a variety. Membranipora aperta, in 'Crag Polyzoa,' may be this variety, as well as the one figured by Manzoni.

This only differs from Membranipora arctica, D'Orb. in Smitt, in the shape of the avicularian mandible.

\section{Membranipora angulosa, Rss. (Pl. XIII. fig. 3.)}

For synonyms see Reuss, Die Foss. Bry. des Oest.-Ung. Mioc. p. 45, pl. x. figs. 13, 14.

PMembranipora antiqua, Busk, Quart. Journ. Micr. Sci. vol. vi. p. 262, pl. $\mathrm{xx}$. fig. 1.

?Mollia antiqua, Smitt, Floridan Bryozoa, pt. ii. p. 12, pl. ii. fig. 73.

Membranipora angulosa, Manzoni, Bri. di Castrocaro, p. 8, pl. i. fig. 11, and other papers.

Eschara excavata, Reuss, Foss. Pol. W. B. p. 72, pl. viii. fig. 36.

The surface of the cell is very minutely granulated. The shape of the area varies from oval to triangular. The raised 
borders of the cell do not always meet, in which case the cells are irregularly oval. The shape of the cells is just the same as in some Eocene specimens in my possession; but, it will be seen, the shape is somewhat variable. The large opening is not the oral aperture, but is covered with a membrane on which is the oral lid, as seen in the right-hand bottom cells. This operculum or lid has a tooth or projection on each side, to which is probably attached the muscle. This is shown in the two right-hand cells. As neither Busk nor Smitt have given particulars of the oral aperture of $M$. antiqua, it makes it somewhat difficult to be sure if Manzoni is correct in giving this as a synonym. The trifoliate shape of the opening of the calcareous area would be produced by a widening of the basal portion.

Abundant in the Eocene, Miocene, and Pliocene from many localities in Austria, Hungary, and Italy, Rhodes (Manz.).

Living: Florida, 29-44 fathoms; Madeira; Naples about $30-40$ fathoms.

Hemeschara trapezoidea, Rss., Bry. v. Crosaro, pl. xxix. fig. 14, is the Hemeschara stadium of this; and the shape of the open area more nearly corresponds with that of the Floridan and Madeira specimens. Reuss has omitted the description of this ; but from the Miocene of San Martino he speaks of an "ästige Biflustra-ähnliche Form."

\section{Micropora impressa, Moll.}

Eschara impressa, Moll, Die Seerinde, p. 57, pl. ii. fig. 9, A-I.

? Cellepora gracilis, v. Münster in Goldf. Petr. Germ. p. 102, pl. xxxvi. fig. 13.

Cellepora gracilis, Reuss, Foss. Polyp. W. B. p. 93, pl. xi. fig. 12.

?Cellepora minuta, Reuss, loc. cit. p. 93, pl. xi. fig. 13.

Eschara andegavensis, Mich. Icon. Zooph. p. 329, pl. lxxviii. fig. 11.

?Eschara nobilis, id. loc. cit. p. 329, pl. lxxix. fig. 1.

Membranipora andegavensis, Busk, Crag Polyz. p. 35, pl, ii. fig. 5.

Membranipora calpensis, Busk, Mar. Polyz. p. 60, pl. civ. figs. 5, 6.

Membranipora bifoliata, Heller, Die Bry. Adr. Meeres, p. 95, pl. 2. fig. 1.

Membranipora andegavensis, Manz. Bry. Foss. Ital. cont. 2, p. 2, pl. i. fig. 2.

Membranipora calpensis, Manz. Supp. alla Fauna Medit. p. 3, figs. 2, 3.

Membranipora gracilis, Reuss, Foss. Bry. Oest.-Ung. Mioc. p. 44, pl. x. figs. 5-7.

The special character of Membranipora appears to be a lid opening out of the membrane covering the aperture; but this is not the case in the present species, in which the oral aperture is surrounded by a calcareous margin, and the operculum is separable and distinct: it therefore ought to be separated from Membranipora. 
There would seem no doubt that this is the species described by Moll. Manzoni's figure, in his Suppl. Fauna Medit., shows the Naples form the best, though in my specimen the border is wider and appears formed of double granulations. There is no explanation of fig. 6 in Busk's Cat., and it is therefore difficult to know what it represents ; and the comparison with Flustra Latreillii, in the same work, must surely be a mistake. Eschara elegans, M.-Edw. ('Eschares fossiles,' p. 337, pl. xii. fig. 13), looks like the Eschara stadium of this species.

Two rosette-plates in the distal wall near the centre. Both these and the lateral plates have an elongated form.

Operculum : little more than half a circle, proximal edge nearly straight, width $0 \cdot 12$ millim., length $0 \cdot 92$.

Loc. Upper Oligocene: Astrupp. Miocene: several places in Austria and Hungary, Doué, Thorigné. Pliocene : Castellarquato, Palermo, Rhodes. Living: Gibraltar (?), Adriatic, 20-55 fathoms (Heller) ; Naples, several layers, incrusting, 20-50 fathoms.

\section{Eschara cervicornis, Pall.}

Eschara undulata, Rss. Foss. Polyp. der W. Tert. p. 68, pl. viii. fig. 24.

This is the species of Milne-Edwards and Busk, and is very abundant at Naples from about 30 fathoms downwards.

The operculum is saddle-shaped, widening out very much at the proximal end; long muscular boss close to the edge ; proximal end 0.18 millim. wide, $0 \cdot 13 \mathrm{long}$, bosses about $0 \cdot 08$ long.

Three distal rosette-plates divided by two raised ridges.

Pliocene: Sicily, Calabria, Belgium (H. de Lehaie), Rhodes (Manz.). Living: Britain (?), Adriatic (H.), France.

\section{Eschara foliacea, Ellis. (Pl. XV. fig. 8.)}

Eschara fascialis, Pall. Elench. p. 42.

Eschara fascialis, Moll, Die Seerinde, p. 36, pl. i. figs. 1, 2.

Eschara foliacea, Milne-Edwards, Sur les Eschares, p. 39, pl. iii. fig. 1, Ann. des Sc. Nat. sér. 2, vol. vi. 1836.

Eschara bidentata, M.-Edw. loc. cit. p. 42, pl. iii. figs. 2, 2 a.

Eschara fascialis, M.-Edw. loc. cit. p. 43, pl. iv. fig. 1.

Eschura foliacea, Heller, Bry. Adr. Meeres, p. 114.

Eschara fascialis, id. loc. cit. p. 114.

Eschara foliacea, Manzoni, Bry. Foss. Ital. cont. 4, p. 18, pl. i. fig. 4, pl. iv. fig. 24 ; and Brioz. di Castrocaro, p. 36.

This occurs elsewhere in both broad and narrow foliations ; and these have been separated by some authors into $E$. foliacea and fascialis, and by Moll were called variety latifolia and var. angustifolia; and in case of the shape requiring to be indicated 


\section{Bryozoa of the Bay of Naples.}

this latter distinction might be used. The shape of the cells and the aperture, however, seems in both to be the same.

There also does not appear to be sufficient reason for separating bidentata, as the raised projection at the side of the mouth is very variable and depends to a great extent upon the age. In the younger cells it is much more apparent, while in the older cells, where the aperture is more surrounded by a subsequent growth, it is scarcely seen. The specimen figured would be bidentata of M.-Edw., stadium angustifolia, Moll; but as this is only a variable difference in the peristome, and not in the oral aperture, there does not seem valid reason for making it even a variety.

I have before (p. 33) called attention to the long spatulate avicularia which are often seen in this species; and the different stages, from the very small avicularium with the small mandible placed at right angles to the axis of the zoœcium, to the large spatulate horizontal avicularium, can be seen in the same piece.

The operculum is somewhat saddle-shaped, about 0.12 millim. wide and about $0 \cdot 16$ millim. long, with large muscular bosses at the side.

Four lateral rosette-plates and two distal, divided by a large ridge running up between them; they are situated at the base of the lateral wall.

Loc. Pliocene: Castrocaro, Leghorn, Sicily, Rhodes. Living: Britain, France (zone prof.), Adriatic; Naples, 30-40 fathoms.

I have two specimens in which, at the end, the two layers separate and end in a funnel-shaped expansion. This is interesting as showing a connexion between the Hemeschara and Eschara stadia.

\section{Eschara verrucosa, Peach. (Pl. XII. figs. 2, 3, 4.)}

Eschara verrucosa, Peach, On a new British Eschara, Royal Inst. of Cornwall, vol. iii. 1868, p. 116, and vol. iv. pl. with p. 88 .

Eschara lunaris, Waters, Bry. from the Plioc. of Bruccoli, Tr. Manch. Geol. Soc. vol. xiv. 1878, p. 475, fig. 9.

Stem cylindrical, dividing dichotomously, six cells in a row ; cells at the growing extremity ovate, near the base hexagonal; mouth orbicular, young cells projecting, old cells deeply immersed, four oral spines on the upper margin of the aperture; proximal edge of operculum straight, distal edge horseshoeshaped; border of the oral aperture sometimes raised in young: cells; semilunar pore below the mouth; avicularium on one side of the cell, with extremely long mandible, surface coarsely 
punctured; ovicells (see fig. 9, loc. cit.) globose, finely punctured.

I am indebted to Dr. Hincks for pointing out that the specimens collected by me are the same as a fragment which Mr. Peach collected and described from Fowey (Cornwall); and although he does not mention any semilunar pore, and describes and figures a vibraculum, I think there cannot be much doubt that they are the same.

The zoœcium of this is very much the same as that of Lepratia ciliata; and Smitt mentions (p. 62, Krit. Fört. 1867, Bih.) "en Eschara-växt" of his Porellina ciliata, which is evidently this species, as the peculiar shape of the aperture is mentioned.

The growing extremities (fig. 4) are different from any of the other Escharce examined by the author. The ends of the lastformed row of zoœcia have a double slope, like the roof of a house, with a raised, rounded, slightly overlapping ridge at the top. On each side of this are usually five tubular holes, and one or two lower down on the side. At the bottom of these tubes is a membrane which has one, two, or even more minute perforations. Fig. $a$ is the ridge of the roof and rosette-pores, magnified eighty-five times.

These are the equivalents of the rosette-plates in Lepralioid forms; and as the growth of the next series takes place from these, their position should be considered in assigning a systematic place to this species. Peach doubts if it should be ranked as an Eschara; but of its systematic position I should not attempt to form an opinion until I had examined in detail the numerous cylindrical Eschara-like fossils.

In transparent sections the cells are often found not to quite join in the centre. In the old cells the semilunar pore often appears circular; but upon examination this is found to arise from it being now, in consequence of the growth of the surrounding walls, a long tubular opening; at the bottom of this tube, however, is seen the original semilunar opening. The avicularia are sometimes bifid at the end; but perhaps this may be a stage of growth.

Operculum (28*) horseshoe-shaped; proximal edge straight, 0.08 millim., widest part $0 \cdot 17$, length $0 \cdot 1$.

Loc. Pliocene: Rametta, Bruccoli (Sicily), Parere (Calabria). Eschara columnaris, Manz., from Castrocaro, looks much like a fragment from near the base. Living: Naples, 40 fathoms, from the Secca. There is a worn fragment in the British Museum, collected from the coast of Norway by R. M'Andrew, which looks like it; but without sections determination is impossible.

[To be continued.] 


\section{$2 \mathrm{BHL}$ Biodiversity Heritage Library}

Waters, Arthur William. 1879. "XI.-On the Bryozoa (Polyzoa) of the Bay of Naples." The Annals and magazine of natural history; zoology, botany, and geology 3, 114-126. https://doi.org/10.1080/00222937908682488.

View This Item Online: https://www.biodiversitylibrary.org/item/81199

DOI: https://doi.org/10.1080/00222937908682488

Permalink: https://www.biodiversitylibrary.org/partpdf/63083

\section{Holding Institution}

Smithsonian Libraries

\section{Sponsored by}

Smithsonian

\section{Copyright \& Reuse}

Copyright Status: Public domain. The BHL considers that this work is no longer under copyright protection.

This document was created from content at the Biodiversity Heritage Library, the world's largest open access digital library for biodiversity literature and archives. Visit BHL at https://www.biodiversitylibrary.org. 